\title{
Quality of life of the elderly in intergenerational cooperation and learning programs
}

\author{
Valerija Rotar', Tamara Poklar Vatovec ${ }^{2}$ \\ 'Community Health Centre Ormož, Ormož, Slovenia \\ 2University of Primorska Faculty of Health Sciences, Izola, Slovenia \\ valerija.rotar@gmail.com; tamara.vatovec@fvz.upr.si
}

\section{Abstract}

Introduction: Demographic change and the weight of an aging society require strategies and long-term solutions to ensure a quality life for the older generations and to maintain intergenerational solidarity at the level of sustainability of society as a whole. Healthy and active aging is not only an indicator of health status, but also means the inclusion of the elderly in social processes in the local and wider community, where they have opportunities and resources to develop new knowledge, skills and enrich their lives. Methods: The survey was conducted from March to April 2021, which included 6o self-employed elderly people from eastern Slovenia. A questionnaire on the frequency of food and beverage consumption was used to assess their eating habits and others related to their quality of life. Results: Most older people buy food and prepare meals regularly. Less than a quarter of the elderly gained weight during the pandemic. They often ate fried foods and rarely ate fish, porridge, and cereals. Most are concerned about the situation; half have been vaccinated and a fifth have survived the Covid-19 virus disease. Discussion and conclusions: The profession of dietitian is underrepresented in work processes, and the inclusion of dietitian in various programs, workshops and promotions is a great opportunity to participate and learn in the local and wider community. Through the transfer of professional knowledge and skills, dietitians can influence management of inappropriate eating habits that lead to malnutrition, fragility and other metabolic deficiencies, and thus significantly affect the quality of life of older people. In the process of learning and socializing, knowledge and interpersonal relationships deepen, which is of great importance for the elderly in making their lives meaningful. A dietitian can be involved as a professional associate at the primary level in the health system and in programs and projects aimed at raising awareness of importance of healthy eating. 
Keywords: healthy aging, intergenerational cooperation, food habits, covid-19 illness

\section{Introduction}

Slovenia is one of many countries with a rapidly aging population. In view of these demographic changes, some reforms are needed at the national level. To ensure the quality of life of aging citizens, remedies and solutions in the form of intergenerational cooperation and solidarity in a close community are needed (Hozjan, 2010).

As the human lifespan lengthens, the need to maintain and preserve the quality of life and independence of our elderly increases (Mihor et al., 2018).

As a result of the aging process, older people need help and a variety of services, either in a formal setting (institutional care, volunteer work, home care) or informally (relatives, neighbours, friends...) (Marjan Cugmas et al., 2021).

Chronic diseases are a major problem in old age (Cijan and Cijan, 2003). The interconnectedness of chronic diseases in elderly patients can lead to frequent hospitalizations, where treatment is prolonged and the recovery process worsens (Poredoš, 2004).

Intergenerational collaboration can have a major positive impact on people's well-being and health. For older people, engaging in such activities leads to minimizing potential problems as they generally improve mood, reduce isolation, strengthen their social network, sense of belonging and sense of importance to society (Macuh, 2019).

A healthy lifestyle is based on a balanced and planned diet and the right amount of physical activity, which in turn can lead to a longer and healthier life. The energy requirement of an elderly person is reduced due to slower basal metabolic rate and less physical activity, also the functions of internal organs are reduced, endocrine system and immune system are less efficient and all these factors can also lead to inadequate absorption of nutrients in the body (Pregelj et al., 2011). The immune system of a person depends on age, diet, metabolism and genetics (Rotovnik Kozjek, 2020).

Active and healthy aging is a process that promotes and strengthens the capabilities of health, safety, and inclusion in society with the long-term goal of improving the health and well-being of older people (Kenda, 2018).

A society's longevity strategy is based on the concept of active aging, i.e. people living active, healthy, independent and safe intergenerational lives in all areas of life, including older people (Bednaš and Kajzer, 2017).

\section{Methods}

The survey was conducted from March to April 2021 and included 60 independent elderly people (70\% women and 30\% men) from Eastern Slovenia. In 
the age group 65 to 75 years there were $68.3 \%$ and in the oldest age group $31.7 \%$ of the elderly. The research was conducted by means of a structured interview with individuals. A short questionnaire on healthy/unhealthy diet (Koch et al., 2014) was used to assess their eating habits and other aspects of their quality of life. For statistical analysis, we used the computer program SPSS version 26. Using the descriptive method, we describe the sample and results using the frequency distribution of responses and mean scores. Statistically significant differences in the variables were determined using the Mann Whitney test. For statistical inference, we considered 0.05 risk levels.

\section{Results}

Table 1 presents the results of the respondents in correlation with the risk factors of unhealthy diet. $16.7 \%$ of the elderly consume 2 meals or less per day. Less than once a day, $20.0 \%$ of the elderly consume vegetables and $25.0 \%$ fruit. 68.3 $\%$ of the elderly consume drinks with added sugar less often and $66.7 \%$ salt after eating meals. Once a week or more, $63.3 \%$ eat fried foods and $61.7 \%$ of the elderly use fat (margarine, butter, cream or lard) when preparing food.

\section{Table 1: The respondents in correlation with risk factors of unhealthy diet}

\begin{tabular}{|c|c|c|c|c|}
\hline Description of risk & Criteria for unhealthy behaviour & Answer & $n$ & $\%$ \\
\hline \multirow{2}{*}{ Number of daily meals } & \multirow{2}{*}{2 or less } & Yes & 10 & 16,7 \\
\hline & & No & 50 & 83,3 \\
\hline \multirow{2}{*}{ Frequency of breakfast } & \multirow{2}{*}{ Never } & Yes & 11 & 18,3 \\
\hline & & No & 49 & 81,7 \\
\hline \multirow{2}{*}{$\begin{array}{l}\text { Milk and dairy products consump- } \\
\text { tion frequency }\end{array}$} & \multirow{2}{*}{ Less than once a day } & Yes & 33 & 55,0 \\
\hline & & No & 27 & 45,0 \\
\hline \multirow{2}{*}{ Frequency of fruit consumption } & \multirow{2}{*}{ Less than once a day } & Yes & 15 & 25,0 \\
\hline & & No & 45 & 75,0 \\
\hline \multirow{2}{*}{ Frequency of vegetable consumption } & \multirow{2}{*}{ Less than once a day } & Yes & 12 & 20,0 \\
\hline & & No & 48 & 80,0 \\
\hline \multirow{2}{*}{ Frequency of red meat consumption } & \multirow{2}{*}{ Three times a week or more } & Yes & 29 & 48,3 \\
\hline & & No & 31 & 51,7 \\
\hline \multirow{2}{*}{$\begin{array}{l}\text { Frequency of fish and sea food con- } \\
\text { sumption }\end{array}$} & \multirow{2}{*}{ Three times a month or less } & Yes & 39 & 65,0 \\
\hline & & No & 21 & 35,0 \\
\hline \multirow{2}{*}{$\begin{array}{l}\text { Frequency of whole-grain cereals } \\
\text { consumption (groups of porridge, } \\
\text { groats...) }\end{array}$} & \multirow{2}{*}{ Three times a month or less } & Yes & 30 & 50,0 \\
\hline & & No & 30 & 50,0 \\
\hline \multirow{2}{*}{$\begin{array}{l}\text { Frequency of fried food consump- } \\
\text { tion }\end{array}$} & \multirow{2}{*}{ Once a week or more } & Yes & 38 & 63,3 \\
\hline & & No & 22 & 36,7 \\
\hline \multirow{2}{*}{ Additional use of salt } & \multirow{2}{*}{ Adding salt without tasting food first } & Yes & 20 & 33,3 \\
\hline & & No & 40 & 66,7 \\
\hline
\end{tabular}


Fat in food preparation

Margarine, butter, cream, lard

\begin{tabular}{ccc} 
Yes & 37 & 61,7 \\
\hline No & 23 & 38,3 \\
\hline Yes & 19 & 31,7 \\
\hline No & 41 & 68,3
\end{tabular}

Drinks with added sugar (fizzy

drinks, still drinks, water with added One to three times a week or more

flavour, fruit syrup)

The questionnaire was used to determine the number of healthy eating habits (scale 1-12). Most elderly 23.3\% scored 7 points, and $3.3 \%$ all points. More than half of the possible points got to $66,6 \%$ seniors (Figure 1 ).

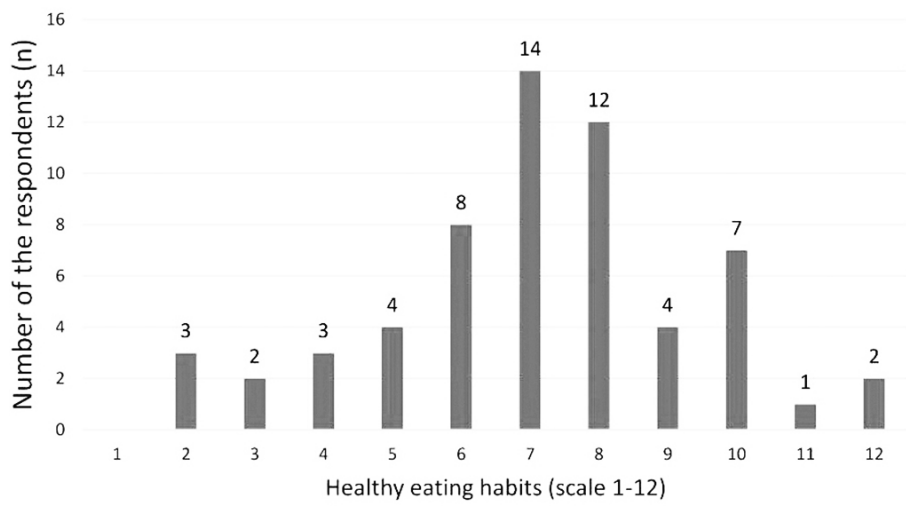

Figure 1: Proportion of elderly and their number of healthy eating habits

Table 2: Results of the questionnaire about life habits

\begin{tabular}{|c|c|c|c|}
\hline Questions & Answers & $n$ & $\%$ \\
\hline \multirow{2}{*}{$\begin{array}{l}\text { Frequency of water and unsweetened beverages. } \\
\text { Less than } 2 \text { glasses a day. }\end{array}$} & Yes & 8 & 13,3 \\
\hline & No & 52 & 86,7 \\
\hline \multirow{2}{*}{ Do you buy food alone? } & Yes & 49 & 81,7 \\
\hline & No & 11 & 18,3 \\
\hline \multirow{2}{*}{ Do you cook meals yourself? } & Yes & 46 & 76,7 \\
\hline & No & 14 & 23,3 \\
\hline \multirow{2}{*}{ You gained weight during Covid-19? } & Yes & 14 & 23,3 \\
\hline & No & 46 & 76,7 \\
\hline \multirow{2}{*}{ Did you have Covid-19? } & Yes & 7 & 11,7 \\
\hline & No & 53 & 88,3 \\
\hline \multirow{2}{*}{ Have you been vaccinated against Covid-19? } & Yes & 36 & 60,0 \\
\hline & No & 24 & 40,0 \\
\hline \multirow{2}{*}{ How do you feel during the Covid-19 pandemic? } & Same as before & 20 & 33,3 \\
\hline & I fell more worried & 40 & 66,6 \\
\hline
\end{tabular}


During the Covid-19 pandemic, $33.3 \%$ of the elderly felt the same as before the pandemic and $66.6 \%$ were a little or a lot more worried than before (Table 2). Those who felt the same during the pandemic as before scored $\mu=8.3$ points $(\mathrm{Me}=7,5)$ with the questionnaire, and the "I was more worried" group scored $\mu=6.6$ points $(\mathrm{Me}=7,0)$. We found a statistically significant difference using the Mann Whitney test $(\mathrm{U}=256,0 ; \mathrm{p}=0$,022). Those who have better eating habits and scored higher feel better and were less worried during a pandemic. Covid-19 disease was had by $11.7 \%$ of elders and $60 \%$ of them were vaccinated.

\section{Discussion}

Based on the questionnaire and their thoughts on the Covid-19 pandemic, we conducted an interview in the form of a dialogue to capture their eating habits and other habits related to a healthy lifestyle. Of concern was the fact that one-fifth of the participants consumed vegetables less than once a day and onefourth consumed fruits less than once a day, which are an important source of vitamins, minerals, fibre, and other health-promoting elements. $16.7 \%$ of older people eat fewer than two meals a day. However, due to the physiological processes of ageing, it is recommended to eat several smaller but nutrient-rich meals with controlled energy intake (Gabrijelčič Blenkuš, et al., 2010). $63.3 \%$ of the elderly consume fried foods once or more a week, and $61.7 \%$ of them also use fat (margarine, butter, cream, animal fat) in their preparation. $33.3 \%$ of the elderly additionally salt their food at the table and $32 \%$ drink sugared drinks 1-3 times a week.

The pandemic has strongly influenced the eating, shopping and living habits of the elderly. In addition, there are movement limitation, changes in physical functioning (decreased musculature, bone density, respiratory capacity, urination problems, vasomotor instability, sensory sensitivity), changes in mental health (depression, social isolation, sadness), as well as eating disorders, orientation difficulties, falls, acute infections, malnutrition and others. This is why a healthy, balanced diet planned according to expert guidelines is so important for a healthy and robust immune system (Skela et al., 2010). Limited access to food during the pandemic period, as well as lack of cooking skills and poor financial situation, are important factors contributing to inadequate and insufficient nutrition, which in turn can negatively affect health and subsequent treatment outcomes (Gregorič et al., 2020). One of the results showed that $33.3 \%$ of the participants felt the same as before the pandemic, but the rest, $66.6 \%$, felt somewhat or much more affected than before. A statistically relevant relationship was found between those who ate well and their worries, as they felt better and less worried than those who did not eat properly. We must point out that independence and quality of life are very important for older people when it comes to choosing food and preparing their own meals. After all, $76.7 \%$ of the participants prepare their own meals and $81.7 \%$ buy their own food. The data clearly shows that the elderly who participated in this research 
eat fried foods and red meat too often, use too much fat, and eat too little vegetables, fish, and seafood. They also tend to add extra salt to their meals. Consumption of grains and porridge is also inadequate. Nearly a quarter have increased body weight. For the elderly, it is important that meals are energetically tailored to their needs. Gender, age, diet, temperature, psychological factors, physical activity and general well-being all play a role (Kobentar and Marinič, 2000).

\section{Conclusions}

Slovenia and the whole of Europe are facing their greatest challenge yet: the demographic crisis and the aging of the population pose unique challenges to human coexistence, intergenerational cooperation and the foundations of solidarity.

In the light of the pandemic of the new coronavirus (Covid-19), the vulnerability of an aging population is becoming clear. The complex process of aging, the cost of chronic disease, impaired physiological function, psychological problems, disability, poverty, elder abuse, increased isolation, and more are frightening signs of the challenges facing our aging society.

Due to poor diet, our elderly do not consume enough fruits and vegetables and do not drink enough fluids. Due to physiological changes in their bodies, their appetite decreases and energy consumption decreases. Therefore, it is necessary to evaluate dietary habits and develop a diet plan based on research findings. This is the only way to prevent malnutrition, frailty syndrome and other diseases related to malnutrition. This is a very good initiative to involve dietitians in the health care system and other similar institutions (nursing homes, hospitals, rehabilitation centres, schools, etc.) where dietitians have not been involved in the work process so far. It is important to point out that we can address the health problems of older people and their unhealthy habits by promoting healthy lifestyles and prevention programs, which are included in many Slovenian nutrition policies.

It is obvious that dietitians are underrepresented in working processes. By including a dietitian in various programs, workshops and actions, we could set a precedent for collaboration and learning in the local community and beyond. With his expertise, a dietitian can address inappropriate eating habits that lead to malnutrition, frailty and other metabolic deficiencies. In this way, he can improve the quality of life of the elderly. Because of his training, a dietitian can participate in numerous projects to promote healthy and active lifestyles and use his knowledge to educate young and old alike about the importance of healthy eating. In addition, a nutritionist can explain the recommended guidelines for a balanced and energy-rich diet and warn against modern trends, marketing and advertising.

There are many programs and projects in Slovenia in which a dietitian can be involved. They may work in health care, as volunteers or in some other 
form of employment, as studies have shown that health is a high priority for the elderly population. Dietitians play an important role in promoting a healthy diet and lifestyle to prolong life and improve its quality, especially in old age. With their skills, they play a key role in intergenerational social interaction; lifelong learning and expanding the network of social relationships with the aim of helping older people find a meaningful role in society and a purpose in their lives.

\section{References}

BEDNAŠ, M. and KAJZER A. (ed.)., 2017. Strategija dolgožive družbe. Ljubljana: Urad Republike Slovenije za makroekonomske analize in razvoj: Ministrstvo za delo, družino, socialne zadeve in enake možnosti.

CIJAN, V. and CIJAN, R., 2003. Zdravstveni, socialni in pravni vidiki starostnikov. Maribor: Visoka zdravstvena šola.

CUGMAS, M., DREMELJ, P., KOGOVŠEK, T., FERLIGOJ, A. and BATAGELJ, Z., 2021. Socialna opora starejših, ki živijo v domačem okolju, v času prvega vala epidemije koronavirusa v Sloveniji. Ars \&Amp; Humanitas, 15(1), 73-90. Available from: https://doi.org/10.4312/ars.15.1.73-90 (Original work published 20. julij 2021)

GABRIJELČIČ BLENKUŠ, M., STANOJEVIĆ JERKOVIĆ, O., ĐUKIČ, B., PREZELJ, M., JEŠE, M., ŠKORNIK TOVORNIK, T.,FAJDIGA TURK, V.,DREV. A., JERIČ I. and TRATNJEK, P., 2010. Prehrana in telesna dejavnost pri starejših-pregled stanja. Ljubljana: Inštitut za varovanje zdravja Republike Slovenije. Available from: https://www.nijz.si/sites/www. nijz.si/files/uploaded/prehranaintelesnadejavnoststarejsih_4940.pdf

GREGORIČ, M., POLIČNIK, R., ĐUKIČ, B., BLAZNIK, U., FAJDIGA TURK, T. and KORDIŠ, T., 202O. Prehranski nasveti namenjeni posameznikom in družinam v času nove virusne bolezni covid-19. Ljubljana: Nacionalni inštitut za javno zdravje.

HOZJAN, T., 2010. Aktualne dejavnosti na področju medgeneracijskega sodelovanja v Sloveniji. Andragoška spoznanja, 16(4), 45-52. Available from: https://doi.org/10.4312/as.16.4.45-52

KENDA, A., 2018. Usmeritve na področju aktivnega staranja. In: TRATNIK VOLASKO, M. (ed.), Starejši kot sedanjost in prihodnost družbe .Ljubljana: Državni svet Republike Slovenije: Varuh človekovih pravic Republike Slovenije, pp. 21-30.

KOBENTAR, R. and MARINIČ, M., 20oo. Organske spremembe in motnje prehranjevanja $\mathrm{v}$ starosti Organic changes and nutritional disorders in old age. Obzornik zdravstvene nege 34(5-6), 209-214. Available from: https://obzornik.zbornica-zveza.si:8443/index.php/ObzorZdravNeg/article/view/2331 
KOCH, V., GABRIJELČIČ BLENKUŠ, M., GREGORIČ, M., KOSTANJEVEC, S., 2014. Risk Factors as a Result of Unhealthy Nutrition in the Adult Population in Slovenia With Regard to Sociodemographic Variables. Zdrav Var, (53), 144-155.

MACUH, B., 2019. Pomen medgeneracijskega sodelovanja za starostnike v tretjem in četrtem življenjskem obdobju. Revija za univerzalno odličnost $8(4), 328-337$.

MIHOR, A., DŽINIĆ, P., VENINŠEK, G. and GABROVEC, B., 2018. Obravnava starostne krhkosti na ravni posameznika - vloga prehrane. In: ARSENIJEVIĆ, O., PODBREGAR, I., ŠPRAJC, P.,TRIVAN, D. and ZIEGLER, Y. (ed.), Organizacija in negotovosti v digitalni dobi: konferenčni zbornik = Organization and uncertaintyin the digital age: conference proceedings 37. mednarodna konferenca o razvoju organizacijskih znanosti, 21-23. marec 2018, Portorož. Maribor: Univerzitetna založba univerze, pp. 732742. Available from: https://press.um.si/index.php/ump/catalog/book/326

POREDOŠ, P., 2004.Zdravstveni problemi starostnikov. Zdravstveni vestnik, 73(10), 753-756. Available from: http://www.dlib.si/details/URN:NBN:SI:doc-AJHRNSHX

PREGELJ, T., BIZJAK, M. IN POKLAR VATOVEC, T., 2011. Smernice in priporočila za zdravo prehranjevanje starostnikov. In: JURDANA, M., POKLAR VATOVEC, T. and PERŠOLJA ČERNE, M. (ed.), Razsežnosti kakovostnega staranja, Koper: Univerza na Primorskem, Znanstveno-raziskovalno središče, Univerzitetna založba Annales, pp. 63-77

ROTOVNIK KOZJEK, N., 2020. Vpliv epidemije covid-19 na zdrav življenjski slog-telesna neaktivnost. In: KRAJC, M. (ed.) Obvladovanje raka v času covida-19 v luči preventive XXVIII. seminar In memoriam dr. Dušana Reje, Ljubljana, 3 december 2020, Ljubljana: Zveza slovenskih društev za boj proti raku : Onkološki inštitut, pp. 51-65.

SKELA SAVIČ, B., ZURC, J. and HVALIČ TOUZERY S., 2010. Staranje populacije, potrebe starostnikov in nekateri izzivi za zdravstveno nego. Zdravstveni vestnik 44(2), 89-100. 